\title{
PENGARUH PROPORSI TELUR DAN GULA SERTA SUHU PENGOVENAN TERHADAP KUALITAS FISIK, KIMIA, DAN ORGANOLEPTIK PADA BOLU BEBAS GLUTEN DARI PASTA UBI KAYU (Manihot Esculenta)
}

\section{The Effect of Egg and Sugar Proportion as Well as Baking Temperature on Physical, Chemical, and Organoleptic Quality of Gluten Free Cake Made of Cassava Paste (Manihot esculenta)}

\author{
Rahma Hambyah Imami*, Aji Sutrisno \\ Jurusan Teknologi Hasil Pertanian, FTP, Universitas Brawijaya Malang \\ JI. Veteran, Malang 65145 \\ *Penulis Korespondensi, Email: rahmahambyah12@gmail.com
}

\begin{abstract}
ABSTRAK
Bolu adalah produk bakery yang dibuat dari adonan tepung terigu, gula, telur, lemak dan bahan pengembang kemudian dipanggang. Namun penggunaan tepung terigu mengakibatkan meningkatnya nilai impor gandum sehingga pada penelitian ini tepung terigu disubtitusi dengan pasta ubi kayu. Penambahan telur dan gula serta penggunaan suhu pengovenan akan mempengaruhi struktur, volume pengembangan, dan warna bolu. Tujuan penelitian ini adalah mengetahui proporsi telur dan gula serta suhu pengovenan yang sesuai sehingga dihasilkan bolu bebas gluten dengan kualitas menyerupai bolu tepung terigu. Penelitian ini menggunakan Rancangan Acak Kelompok Faktorial dengan dua faktor. Faktor I adalah proporsi telur dan gula $(\mathrm{g} / \mathrm{g})$ yaitu 120:90, 140:70, 160:50. Faktor II adalah suhu pengovenan yaitu $150^{\circ} \mathrm{C}$ dan $170^{\circ} \mathrm{C}$. Hasil penelitian menunjukkan bahwa kedua faktor berpengaruh nyata $(\alpha=0.05)$ terhadap volume pengembangan, porositas, warna crust, springiness, dan hardness. Perlakuan terbaik adalah perlakuan proporsi telur dan gula $160 \mathrm{~g}$ : 50 g pada suhu pengovenan $170^{\circ} \mathrm{C}$.
\end{abstract}

Kata Kunci: Bolu, Gula, Suhu, Pengovenan Telur

\section{ABSTRACT}

Cake is a bakery product made from a mixture of flour, sugar, egg, fat and leavening agent and then baked. However, the use of wheat flour resulted in increased value of wheat imports from year to year. So in this study, wheat flour was replaced by cassava paste. Addition of eggs and sugars as well as the baking temperature would affect the structure, volume development, and color of cake. The purpose of this study was to observe the proportion of eggs with sugar and the baking temperature used to produce gluten-free cake with similar characteristic cake from wheat flour. This study used Factorial Randomized Block Design with 2 factors. Factor I was the proportion of eggs and sugar that were $120 \mathrm{~g}: 90 \mathrm{~g}$, $140 \mathrm{~g}: 70 \mathrm{~g}, 160 \mathrm{~g}: 50 \mathrm{~g}$. Factor I/ was the baking temperature that were $150^{\circ} \mathrm{C}$ and $170^{\circ} \mathrm{C}$. The results showed that the egg and sugar proportion as well as baking temperature had significant effect in volume development, porosity, crust color, springiness, and hardness. The best gluten-free cake treatment was the treatment of egg and sugar proportion of $160 \mathrm{~g}: 50 \mathrm{~g}$ as well as baking temperature of the $170^{\circ} \mathrm{C}$.

Keyword: Baking Temperature, Cake, Egg, Sugar

\section{PENDAHULUAN}

Bolu merupakan produk bakery yang terbuat dari adonan tepung terigu, telur, gula, lemak, dan bahan pengembang yang kemudian dioven. Namun penggunaan tepung terigu 
mengakibatkan meningkatnya nilai impor gandum dari tahun 2009 hingga 2015 dari 9 juta USD menjadi 56 juta USD (Kemendag, 2016). Salah satu bahan pangan lain yang dapat menggantikan terigu adalah ubi kayu.

Ubi kayu biasanya diolah menjadi tepung ubi kayu dan tapioka kemudian diaplikasikan pada produk bakery. Namun, hal tersebut menyebabkan produk yang dihasilkan memiliki tekstur yang lebih keras dengan warna yang lebih pucat. Menurut penelitian Sanful dan Sophia (2014), cake yang dibuat dengan ditambahkan 30\% tepung ubi kayu dari keseluruhan jumlah tepung menghasilkan warna yang lebih pucat dan aroma khas ubi kayu yang kuat. Selain itu, pembuatan cake menggunakan tepung ubi kayu pada konsentrasi yang tinggi menghasilkan volume pengembangan spesifik yang lebih rendah (El-Faham et al., 2014). Pada penelitian ini dipilih pasta ubi kayu sebagai pengganti tepung karena pembuatan pasta ubi kayu lebih sederhana serta mampu memperbaiki kualitas sensori bolu yang dihasilkan.

Penambahan gula dan telur pada bolu akan mempengaruhi kualitas bolu. Gula mampu meningkatkan suhu koagulasi protein saat proses pengovenan sehingga dapat berjalan bersamaan dengan terbentuknya gas karbondioksida dan terbentuk struktur bolu menjadi berpori seragam dan porous (Bennion and Bamford, 1997). Telur akan mempengaruhi volume pengembangan bolu. Hal ini disebabkan kandungan protein pada putih telur yang dapat membentuk busa dimana mampu menahan udara yang masuk ke adonan sehingga menyebabkan pengembangan volume (Koswara, 2009). Suhu pengovenan yang sesuai diperlukan untuk memaksimalkan terjadinya reaksi kimia yang terjadi selama proses pengovenan. Peningkatan suhu pengovenan akan meningkatkan volume pengembangan dan tekstur. Namun, peningkatan suhu yang terlalu tinggi menyebabkan turunnya kualitas akhir bolu (Sani et al., 2014).

Penelitian ini bertujuan untuk mengetahui proporsi telur dan gula serta suhu pengovenan yang sesuai sehingga dihasilkan bolu bebas gluten dengan kualitas menyerupai bolu berbahan dasar tepung terigu.

\section{BAHAN DAN METODE}

Penelitian ini dilakukan di Laboratorium Pengolahan dan Rekayasa Pangan dan Hasil Pertanian, Laboratorium Kimia dan Biokimia Pangan, dan Laboratorium Sensori, Jurusan Teknologi Hasil Pertanian, Fakultas Teknologi Pertanian, Universitas Brawijaya, Malang pada bulan Februari 2017 sampai Mei 2017.

\section{Bahan}

Bahan yang digunakan dalam pembuatan bolu bebas gluten adalah ubi kayu, telur, gula (Gulaku), susu bubuk (Indomilk), garam (Kapal), dan double acting baking powder. Bahan yang digunakan dalam uji kimia adalah eter, etanol $10 \%$ dan $80 \%, \mathrm{HCl} 25 \%, \mathrm{NaOH}$ $45 \%$, akuades, reagen Nelson, $\mathrm{Cu}_{2} \mathrm{O}$, reagen arsenomolibdat, $\mathrm{K}_{2} \mathrm{SO}_{4}, \mathrm{CuSO}_{4}, \mathrm{H}_{2} \mathrm{SO}_{4}, \mathrm{NaOH}$ $30 \%, \mathrm{H}_{3} \mathrm{BO}_{3} 4 \%$, indikator Kjeldahl, $\mathrm{HCl}, \mathrm{H}_{2} \mathrm{SO}_{4} 0.325 \mathrm{~N}, \mathrm{NaOH} 1.25 \mathrm{~N}$, etanol $95 \%$.

\section{Alat}

Alat yang digunakan dalam pembuatan bolu bebas gluten adalah meat grinder (Geepas MG-30), timbangan digital (Camry), mixer (Kirin), oven listrik (Maspion). Alat yang digunakan untuk uji fisik dan kimia meliputi software ImageJ, Texture Analyzer Brookfield CT V1.4 Build 17, dan Colour Reader (Konica Minolta), oven listrik (Memmert tipe U 30), timbangan analitik (XP-1500), shaker, spektrofotometer, rangkaian destruksi, lemari asam, destilator (Buchi K-30), buret, dan glassware.

\section{Desain Penelitian}

Penelitian ini menggunakan Rancangan Acak Kelompok (RAK) dengan dua faktor. yaitu proporsi telur dan gula yang terdiri dari 3 level yaitu $120 \mathrm{~g}: 90 \mathrm{~g}(\mathrm{G} 1), 140 \mathrm{~g}: 70 \mathrm{~g}$ (G2), $160 \mathrm{~g}: 50 \mathrm{~g}(\mathrm{G} 3)$ dan suhu pengovenan yang terdiri 2 level yaitu $150^{\circ} \mathrm{C}$ (S1) dan $170^{\circ} \mathrm{C}$ (S2) sehingga diperoleh 6 kombinasi perlakuan dengan ulangan 3 kali. Data hasil pengamatan 
dianalisis dengan Analysis of Variance (ANOVA). Jika hasil uji menunjukkan ada pengaruh, maka dilanjutkan dengan uji Beda Nyata Terkecil (BNT), Duncan Mulitiple Range Test (DMRT), atau Friedman dengan nilai $\alpha=0.05$. Perhitungan ANOVA, BNT, DMRT, dan Friedman dilakukan menggunakan aplikasi Minitab 16. Pemilihan perlakuan terbaik dengan metode Attribute (Zeleny, 1982).

\section{Tahapan Penelitian}

a. Pembuatan pasta ubi kayu

Ubi kayu dikupas, dicuci, dipotong dengan panjang 5-7 cm, lalu direbus selama 20-25 menit hingga matang. Kemudian ditiriskan dan didinginkan dalam lemari pendingin bersuhu 5C selama 24 jam. Ubi kayu kemudian dihaluskan menggunakan meat grinder sehingga diperoleh pasta ubi kayu.

\section{b. Pembuatan bolu bebas gluten}

Telur dan gula (120g:90g, 140g:70g, 160g:50g) dikocok menggunakan mixer hingga mengembang. Kemudian dimasukkan $120 \mathrm{~g}$ pasta ubi kayu dan dikocok kembali hingga merata. Lalu ditambahkan $30 \mathrm{~g}$ susu bubuk dan $0.5 \mathrm{~g}$ garam dan dikocok kembali. Kemudian ditambahkan $0.5 \mathrm{~g}$ baking powder dan diaduk balik hingga merata. Adonan lalu dimasukkan dalam loyang dan dipanggang pada suhu $150^{\circ} \mathrm{C}$ dan $170^{\circ} \mathrm{C}$.

\section{Metode}

Pengamatan fisik meliputi volume pengembangan (Hartajanie dan Ranie, 2010), porositas menggunakan Software ImageJ (Lin, 2014), warna crust dan crumb menggunakan metode Colour Reader Test (Yuwono dan Susanto, 1998), profil tekstur (cohesiveness, springiness, hardness) metode Texture Profile Analyzer (Lukman et al., 2009). Pengamatan kimia meliputi kadar air metode oven dan kadar pati metode hidrolisis asam (AOAC, 1999), kadar lemak metode soxhlet dan kadar karbohidrat metode by difference (Sudarmadji et al., 1997), kadar protein metode Kjeldahl dan kadar abu (AOAC, 1995), uji organoleptik metode hedonik dan skoring (Kartika dan Supartono, 1988).

\section{Prosedur Analisis}

a. Analisis volume pengembangan (Hartajanie dan Ranie, 2010)

Ukur volume adonan roti sebelum dioven dengan mengukur panjang $\mathrm{x}$ lebar $\mathrm{x}$ tinggi dengan menggunakan penggaris. Bolu yang telah dioven didinginkan selam 20 menit. Dihitung volume bolu dengan mengukur panjang $\mathrm{x}$ lebar $\mathrm{x}$ tinggi bolu. Persentase volume pengembangan bolu adalah $\frac{\text { volume roti }}{\text { volume adonan }} \times 100 \%$

b. Analisis porositas dengan Software ImageJ (Lin, 2014)

Bolu diiris 1-2 cm lalu dilakukan scan. Hasil scan diseleksi dan dipotong menjadi $4 \times 4 \mathrm{~cm}$ lalu diolah menggunakan software ImageJ.

c. Analisis warna crust dan crumb metode Colour Reader Test (Yuwono dan Susanto, 1998) Bolu yang telah dipotong dimasukkan dalam plastik bening. Dihidupkan color reader. Diatur tombol pembacaan $\mathrm{L}, \mathrm{a}^{*}, \mathrm{~b}^{*}$ kemudian tekan tombol target dan diarahkan pada bolu dalam plastik. Hasil pembacaan $L, a^{*}, b^{*}$ kemudian dicatat.

d. Analisis tekstur metode Texture Profile Analyzer (TPA) (Lukman et al., 2009). Alat TPA diatur sesuai kebutuhan. Bolu yang dipotong diletakkan pada meja kerja TPA dan diberi penekanan sebanyak dua kali menggunakan probe TA4/1000.

e. Uji organoleptik metode hedonik dan skoring (Kartika dan Supartono, 1988)

Uji organoleptik dilakukan pada warna crust dan crumb, aroma, tekstur, porositas, rasa dan penilaian keseluruhan yang dilakukan dengan metode uji hedonik dan skoring pada 30 panelis tidak terlatih. 
HASIL DAN PEMBAHASAN

\section{Karakteristik Bahan Baku}

Tabel 1. Data Analisis Bahan Baku

\begin{tabular}{lcc}
\hline \multicolumn{1}{c}{ Parameter } & Pasta Ubi Kayu & Ubi Kayu Segar \\
\hline Kadar air $(\% \mathrm{~b} / \mathrm{b})$ & $66.70 \pm 0.53$ & $60 \%^{\mathrm{a}}$ \\
Kadar pati $(\% \mathrm{~b} / \mathrm{b})$ & $10.74 \pm 0.55$ & $37.5 \%^{\mathrm{a}}$ \\
Kadar protein $(\% \mathrm{~b} / \mathrm{b})$ & $1.01 \pm 0.74$ & $0.8 \%^{\mathrm{a}}$ \\
Kadar lemak $(\% \mathrm{~b} / \mathrm{b})$ & $0.29 \pm 0.28$ & $0.3 \%^{\mathrm{a}}$ \\
Kadar abu $(\% \mathrm{~b} / \mathrm{b})$ & $0.73 \pm 0.01$ & $1.5^{\mathrm{a}}$ \\
\hline
\end{tabular}

Sumber: Sunarto (2002)

Kadar air pasta ubi kayu memiliki nilai yang lebih tinggi (66.7\%) sedangkan kandungan kimia yang lainnya memiliki nilai yang lebih rendah dibandingkan dengan ubi kayu segar. Proses perebusan pada pembuatan pasta ubi kayu menyebabkan beberapa komponen larut air serta terjadi terbukanya ikatan penyusun senyawa sehingga terjadi gelatinisasi pati, denaturasi protein, serta hidrolisis lemak.

\section{Volume Pengembangan}

Volume pengembangan adalah kemampuan bolu dalam mempertahankan gas yang dihasilkan selama proses pengovenan.

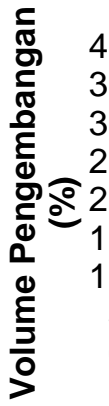

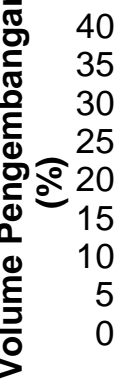

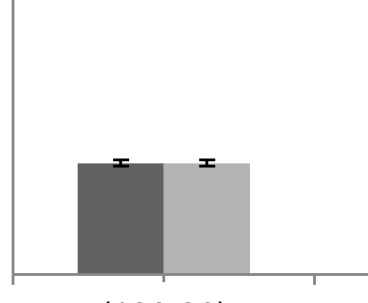

$(120: 90)$

$(140: 70)$

Proporsi telur : gula $(\mathbf{g} / \mathbf{g})$

Gambar 1. Grafik Rerata Volume Pengembangan Bolu Bebas Gluten Akibat Perlakuan Proporsi Telur dan Gula serta Suhu Pengovenan

Gambar 1 menunjukkan bahwa peningkatan proporsi telur dan gula serta suhu pengovenan menyebabkan peningakatan volume pengembangan. Berdasarkan ANOVA, kedua faktor berpengaruh nyata terhadap volume pengembangan bolu. Nilai volume pengembangan tertinggi adalah pada perlakuan proporsi telur dan gula $160 \mathrm{~g}: 50 \mathrm{~g}$ dengan suhu pengovenan $170^{\circ} \mathrm{C}$ yaitu $33.82 \%$. Hal ini diduga karena kandungan telur dalam jumlah tinggi. Putih telur mampu menghasilkan busa yang berfungsi untuk memperangkan udara dan gas karbondioksida dari bahan pengembang sehingga menyebabkan pengembangan volume (Belitz et al., 2009).

Penambahan gula berfungsi untuk menstabilkan pembentukan busa dan menyebabkan busa yang terbentuk lebih elastis sehingga mampu menangkap gas karbondioksida yang berasal dari bahan pengembang (Phillips, 2000). Menurut Sozer et al. (2011) peningkatan konsentrasi gula dalam adonan yang berasosiasi dengan busa putih telur akan menghasilkan gelembung udara yang lebih halus dengan volume yang lebih tinggi. Suhu pengovenan yang lebih tinggi, juga akan menyebabkan peningkatan volume. Hal ini disebabkan karena suhu pengovenan yang semakin tinggi akan menginisiasi terjadinya reaksi kimia dan meningkatkan produksi gas karbondioksida sehingga meningkatkan volume produk (Sani et al., 2014). 


\section{Porositas}

Porositas adalah pori yang terbentuk dari gas karbondioksida yang dihasilkan oleh bahan pengembang dan udara yang terperangkap dalam adonan bolu selama proses pengovenan.



Gambar 2. Grafik Rerata Porositas Bolu Bebas Gluten Akibat Perlakuan Proporsi Telur dan Gula serta Suhu Pengovenan

Gambar 2 menunjukkan bahwa peningkatan proporosi telur dan gula serta suhu pengovenan menyebabkan peningkatan nilai porositas. Berdasarkan ANOVA, kedua faktor memberikan pengaruh nyata terhadap nilai porositas bolu. Nilai porositas tertinggi adalah pada perlakuan proporsi telur dan gula $160 \mathrm{~g}: 50 \mathrm{~g}$ dengan suhu pengovenan $170^{\circ} \mathrm{C}$ yaitu $0.017 \mathrm{~mm}^{2}$. Hal ini diduga karena jumlah telur yang tinggi akan menyebabkan terbentuknya busa yang stabil serta elastis sehingga kemampuan menahan gas karbondioksida yang dihasilkan semakin tinggi. Semakin tinggi kemampuan untuk menahan gas karbondioksida maka nilai porositas akan semakin besar (Mudjisihono et al., 2000). Penambahan gula akan menyebabkan pembentukan busa yang stabil dan elastis sehingga mampu menangkap gas karbondioksida yang berasal dari bahan pengembang (Phillips, 2000). Penggunaan suhu pengovenan yang lebih tinggi terjadi ekspansi gelembung udara secara maksimal sehingga meningkatkan ukuran pori yang terbentuk. Menurut Ureta et al. (2014) pada suhu yang lebih tinggi akan menghasilkan pori dengan bentuk yang seragam dengan luas area yang lebih besar.

\section{Cohesiveness}

Cohesiveness atau kekompakan adalah rasio dari luasan di bawah kurva pada tekanan kedua (A2) dibagi dengan luasan di bawah kurva pada tekanan pertama (A1).

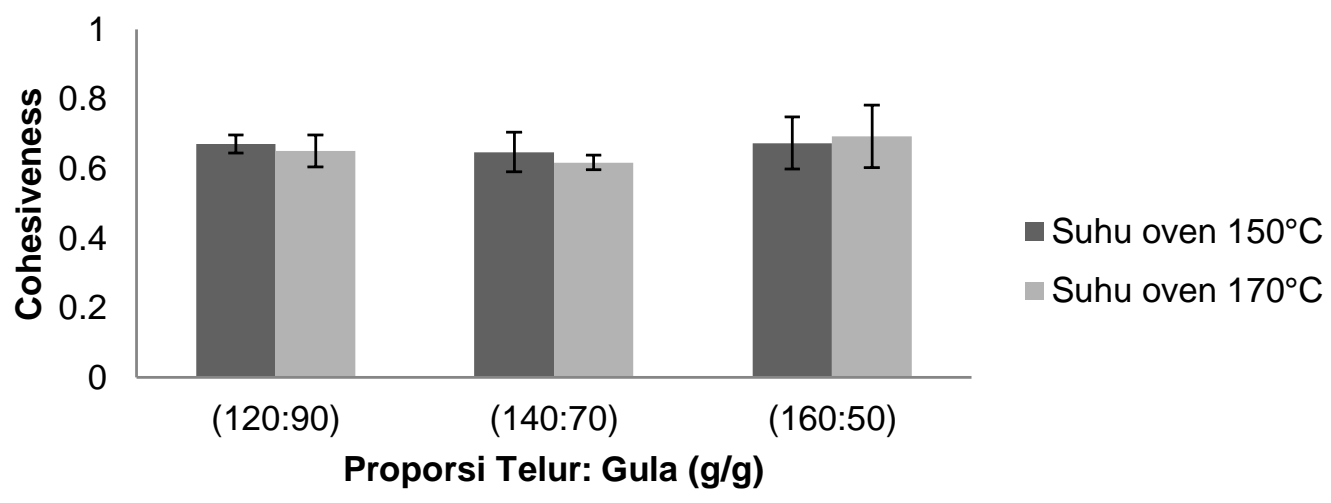

Gambar 3. Grafik Rerata Springiness Bolu Bebas Gluten Akibat Perlakuan Proporsi Telur dan Gula serta Suhu Pengovenan 
Gambar 3 menunjukkan bahwa nilai cohesiveness menunjukkan peningkatan seiring dengan meningkatnya proporsi telur dan gula namun cenderung menurun seiring dengan peningkatan suhu pengovenan. Berdasarkan ANOVA, kedua faktor tidak memberikan pengaruh nyata terhadap nilai cohesiveness bolu. Perlakuan proporsi telur dan gula $160 \mathrm{~g}$ : $50 \mathrm{~g}$ dengan suhu pengovenan $170^{\circ} \mathrm{C}$ memiliki nilai cohesiveness tertinggi (0.69) diduga karena telur dalam konsentrasi tinggi mampu membentuk busa yang semakin stabil sehingga menyebabkan interaksi antar komponen dalam bolu menjadi kuat dan membentuk matriks gel adonan yang kokoh. Matriks gel yang kokoh menghasilkan struktur crumb yang kokoh pula sehingga meningkatkan nilai kekompakan (Jonathan et al., 2016).

\section{Springiness}

Springiness atau elastisitas adalah kemampuan suatu produk pangan untuk kembali ke bentuk semula setelah diberi tekanan.

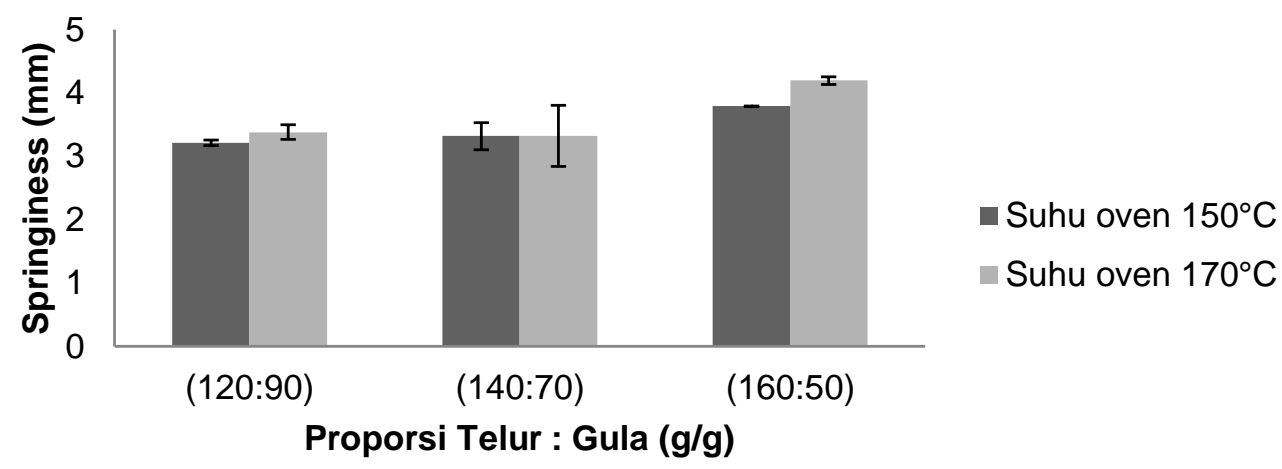

\section{Gambar 4. Grafik Rerata Elastisitas Bolu Bebas Gluten Akibat Perlakuan Proporsi Telur dan Gula serta Suhu Pengovenan}

Gambar 4 menunjukkan bahwa peningkatan proporosi telur dan gula serta suhu pengovenan menyebabkan nilai springiness meningkat. Berdasarkan ANOVA, faktor porporsi telur dan gula berpengaruh nyata terhadap nilai springiness bolu. Nilai springiness tertinggi adalah pada perlakuan proporsi telur dan gula $160 \mathrm{~g}: 50 \mathrm{~g}$ yaitu $3.98 \mathrm{~mm}$. Nilai elastisitas yang tinggi diduga berkaitan dengan kemampuan telur dalam membentuk busa. Pembentukan busa yang stabil menyebabkan adonan mampu memerangkap gas karbondioksida sehingga meyebabkan pembentukan pori dan meningkatkan elastisitas. Menurut Jonathan et al. (2016) peningkatan kuning telur dalam adonan menyebabkan sistem emulsi yang stabil sehingga busa yang terbentuk mampu memerangkap dan menahan udara dalam adonan. Hal ini menyebabkan kemampuan udara untuk mendorong matriks gel meningkat saat pengovenan sehingga kemampuan cake untuk kembali ke bentuk semula setelah diberi tekanan semakin meningkat.

\section{Hardness}

Nilai hardness atau kekerasan ditunjukkan oleh nilai pucak tertinggi yang dihasilkan dari siklus pertama pengukuran (setelah produk ditekan pertama kalinya). 


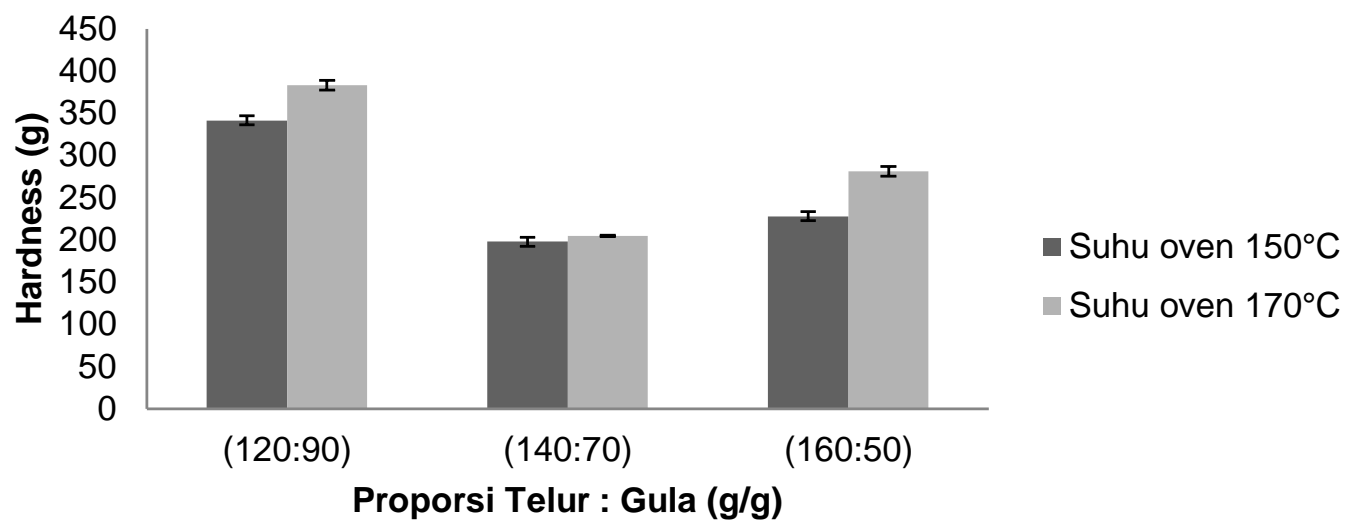

Gambar 5. Grafik Rerata Kekerasan Bolu Bebas Gluten Akibat Perlakuan Proporsi Telur dan Gula serta Suhu Pengovenan

Gambar 5 menunjukkan bahwa nilai hardness cenderung menurun seiring dengan meningkatnya proporsi telur dan gula namun meningkat seiring dengan peningkatan suhu pengovenan yang diberikan. Berdasarkan ANOVA, kedua faktor memberikan pengaruh nyata terhadap nilai hardness bolu. Nilai hardness tertinggi adalah pada perlakuan proporsi telur dan gula $120 \mathrm{~g}: 90 \mathrm{~g}$ dengan suhu pengovenan $170^{\circ} \mathrm{C}$ yaitu $393.03 \mathrm{~g}$. Tingginya nilai hardness diduga karena penurunan jumlah telur dalam adonan. Penurunan jumlah kuning telur menyebabkan pembentukan busa yang kurang stabil sehingga kemampuan untuk memerangkap udara semakin menurun (Jonathan et al., 2016).

Semakin sedikit udara yang terperangkap dalam adonan, maka pori yang terbentuk semakin sedikit sehingga meningkatkan kekerasan. Gula dalam konsentrasi yang telalu tinggi mampu menghambat proses koagulasi protein selama proses pengovenan sehingga menghasilkan volume spesifik yang rendah dengan tekstur yang padat (firm). Proses koagulasi protein akan dihambat oleh gula dengan cara meningkatkan suhu koagulasi, dimana gula akan terdispersi di antara molekul protein sehingga mengganggu molekul protein yang berikatan saat terjadi koagulasi (Sinha, 2007). Hal ini menyebabkan bolu tidak mengalami koagulasi dan tidak dapat memperangkap gas karbondioksida dan udara kedalam adonan sehingga menurunkan volume dan menyebabkan tekstur menjadi lebih keras.

Peningkatan suhu pengovenan juga akan meningkatkan nilai kekerasan. Mohamad et al. (2015) menyatakan bahwa kekerasan pada bolu disebabkan karena tingginya transfer massa dan panas karena proses evaporasi yang terjadi pada suhu tinggi menyebabkan terbentuk crust yang lebih tebal.

\section{Warna}

a. Crust

Tabel 2 menunjukkan bahwa peningkatan proporsi telur dan gula akan meningkatkan nilai kecerahan, kemerahan, dan kekuningan bolu. Sedangkan peningkatan suhu pengovenan akan menurunkan nilai kecerahan dan kekuningan, namun meningkatkan nilai kemerahan bolu. Nilai kecerahan dan kekuningan yang tinggi menunjukkan pembentukan warna coklat akibat reaksi karamelisasi dan Maillard yang rendah. Penurunan jumlah telur dan gula akan menyebabkan pembentukan warna coklat yang kurang pekat. Selain itu kandungan karotenoid pada kuning telur juga menyebabkan warna crust yang terbentuk lebih cerah (Goranova et al., 2015). Pada suhu $150^{\circ} \mathrm{C}$ reaksi karamelisasi dan Maillard berjalan yang lebih lambat dibandingkan pada suhu $170^{\circ} \mathrm{C}$ sehingga memiliki nilai kecerahan dan kekuningan yang tinggi. Sedangkan nilai kemerahan pada suhu $170^{\circ} \mathrm{C}$ memiliki lebih tinggi dibandingkan dengan suhu $150^{\circ} \mathrm{C}$ disebabkan karena terjadi peningkatan reaksi karamelisasi dan Maillard, 
dimana peningkatan reaksi ini juga akan meningkatkan nilai kemerahan (Ganbari and Nader, 2015).

Tabel 2. Pengaruh Proporsi Telur dan Gula serta Suhu Pengovenan terhadap Warna Crust Bolu Bebas Gluten

\begin{tabular}{cccc}
\hline $\begin{array}{c}\text { Proporsi Telur : Gula, } \\
\text { Suhu Pengovenan }\end{array}$ & $\begin{array}{c}\text { Rerata Nilai } \\
\text { Kecerahan (L) }\end{array}$ & $\begin{array}{c}\text { Rerata Nilai } \\
\text { Kemerahan (a*) }\end{array}$ & $\begin{array}{c}\text { Rerata Nilai } \\
\text { Kekuningan (b*) }\end{array}$ \\
\hline $120: 90,150^{\circ} \mathrm{C}(\mathrm{G} 1 \mathrm{~S} 1)$ & $65.73 \pm 0.21^{\mathrm{d}}$ & $10.00 \pm 0.20^{\mathrm{b}}$ & $27.70 \pm 0.21^{\mathrm{c}}$ \\
$140: 70,150^{\circ} \mathrm{C}(\mathrm{G} 2 \mathrm{~S} 1)$ & $70.00 \pm 0.95^{\mathrm{b}}$ & $10.70 \pm 0.82^{\mathrm{b}}$ & $31.00 \pm 0.95^{\mathrm{b}}$ \\
$160: 50,150^{\circ} \mathrm{C}(\mathrm{G} 3 \mathrm{~S} 1)$ & $72.20 \pm 0.61^{\mathrm{a}}$ & $11.23 \pm 1.11^{\mathrm{b}}$ & $33.50 \pm 0.55^{\mathrm{a}}$ \\
$120: 90,170^{\circ} \mathrm{C}(\mathrm{G} 1 \mathrm{~S} 2)$ & $65.33 \pm 0.23^{\mathrm{d}}$ & $10.93 \pm 0.15^{\mathrm{b}}$ & $27.30 \pm 0.23^{\mathrm{c}}$ \\
$140: 70,170^{\circ} \mathrm{C}(\mathrm{G} 2 \mathrm{~S} 2)$ & $67.87 \pm 0.71^{\mathrm{c}}$ & $11.10 \pm 0.35^{\mathrm{b}}$ & $29.90 \pm 0.71^{\mathrm{b}}$ \\
$160: 50,170^{\circ} \mathrm{C}$ (G3S2) & $69.10 \pm 0.66^{\mathrm{bc}}$ & $13.07 \pm 0.55^{\mathrm{a}}$ & $31.10 \pm 0.66^{\mathrm{b}}$ \\
\hline
\end{tabular}

Keterangan: Data merupakan rerata dari 3 ulangan

Angka yang disertai huruf yang berbeda menunjukkan berbeda nyata pada selang kepercayaan $95 \%$ atau $\alpha=0.05$

\section{b. Crumb}

Tabel 3. Pengaruh Proporsi Telur dan Gula serta Suhu Pengovenan terhadap Warna Crumb Bolu Bebas Gluten

\begin{tabular}{cccc}
\hline $\begin{array}{c}\text { Proporsi Telur : Gula, } \\
\text { Suhu Pengovenan }\end{array}$ & $\begin{array}{c}\text { Rerata Nilai } \\
\text { Kecerahan (L) }\end{array}$ & $\begin{array}{c}\text { Rerata Nilai } \\
\text { Kemerahan (a*) }\end{array}$ & $\begin{array}{c}\text { Rerata Nilai } \\
\text { Kekuningan (b*) }\end{array}$ \\
\hline $120: 90,150^{\circ} \mathrm{C}(\mathrm{G} 1 \mathrm{~S} 1)$ & $59.70 \pm 0.80^{\mathrm{a}}$ & $-1.10 \pm 0.95^{\mathrm{a}}$ & $26.91 \pm 2.10^{\mathrm{a}}$ \\
$140: 70,150^{\circ} \mathrm{C}(\mathrm{G} 2 \mathrm{~S} 1)$ & $61.89 \pm 0.82^{\mathrm{a}}$ & $-0.53 \pm 1.74^{\mathrm{a}}$ & $27.44 \pm 1.78^{\mathrm{a}}$ \\
$160: 50,150^{\circ} \mathrm{C}(\mathrm{G} 3 \mathrm{~S} 1)$ & $62.06 \pm 0.53^{\mathrm{a}}$ & $-0.30 \pm 1.40^{\mathrm{a}}$ & $28.69 \pm 0.47^{\mathrm{a}}$ \\
$120: 90,170^{\circ} \mathrm{C}(\mathrm{G} 1 \mathrm{~S} 2)$ & $60.56 \pm 0.21^{\mathrm{a}}$ & $-2.27 \pm 1.29^{\mathrm{a}}$ & $28.43 \pm 1.72^{\mathrm{a}}$ \\
$140: 70,170^{\circ} \mathrm{C}(\mathrm{G} 2 \mathrm{~S} 2)$ & $60.68 \pm 0.25^{\mathrm{a}}$ & $-1.37 \pm 0.50^{\mathrm{a}}$ & $28.72 \pm 0.57^{\mathrm{a}}$ \\
$160: 50,170^{\circ} \mathrm{C}(\mathrm{G} 3 \mathrm{~S} 2)$ & $60.73 \pm 0.52^{\mathrm{a}}$ & $-1.20 \pm 0.56^{\mathrm{a}}$ & $30.08 \pm 1.03^{\mathrm{a}}$ \\
\hline
\end{tabular}

Keterangan: Data merupakan rerata dari 3 ulangan

Angka yang disertai huruf yang sama menunjukkan tidak berbeda nyata pada selang kepercayaan $95 \%$ atau $\alpha=0.05$

Tabel 3 menunjukkan bahwa peningkatan proporsi telur dan gula akan meningkatkan nilai kecerahan, kemerahan, dan kekuningan bolu. Sedangkan peningkatan suhu pengovenan akan menurunkan nilai kecerahan dan kemerahan, namun meningkatkan nilai kekuningan bolu. Nilai kecerahan, kemerahan, dan kekuningan yang tinggi diduga karena memiliki jumlah telur yang lebih banyak dalam adonan. Nilai kecerahan dan kekuningan crumb dipengaruhi oleh bahan yang ditambahkan pada adonan. Dalam hal ini telur berperan dominan dalam pembentukan warna crumb. Telur mengandung pigmen karotenoid yang berwarna merah kekuningan sehingga menyebabkan warna crumb yang dihasilkan berwarna kuning cerah (Goranova et al., 2015).

\section{Uji Organoleptik \\ a. Metode hedonik}

Metode hedonik adalah metode yang mengukur tingkat penerimaan panelis berdasarkan tingkat kesukaan terhadap suatu produk.Penilaian tiap parameter yang diberikan digambarkan melalui skala angka 1-5 yang berarti dari sangat tidak suka hingga sangat suka. Tabel 4 menunjukkan bahwa proporsi telur dan gula $140 \mathrm{~g}: 70 \mathrm{~g}$ dengan suhu pengovenan $150^{\circ} \mathrm{C}$ memiliki nilai penerimaan tertinggi (3.87) karena diduga memiliki karaketristik yang mirip dengan bolu yang ada di pasaran. Kandungan lemak serta gula yang ditambahkan mampu menghasilkan rasa bolu yang enak. Menurut Kusinska (2007) pembuatan half short cake dengan penambahan gula sebesar $72 \mathrm{gr} / 120 \mathrm{gram}$ tepung menghasilkan rasa half short cake yang baik dan khas. Aroma pada bolu dihasilkan dari penambahan telur yang muncul ketika dilakukan proses pengovenan. Telur akan memproduksi senyawa aroma seperti 
aldehid yang mampu menghasilkan aroma seperti buah dan mentega, serta senyawa pirazin yang mampu menghasilkan aroma khas dipanggang pada bolu (Bayon et al., 2007). Gula juga berperan dalam membentuk aroma bolu melalui reaksi karamelisasi dan reaksi Maillard (Bennion and Bamford, 1997).

Tabel 4. Data Hasil Uji Hedonik

\begin{tabular}{cccccccc}
\hline $\begin{array}{c}\text { Proporsi Telur: Gula, } \\
\text { Suhu Pengovenan }\end{array}$ & $\begin{array}{c}\text { Warna } \\
\text { Crust }\end{array}$ & $\begin{array}{c}\text { Warna } \\
\text { Crumb }\end{array}$ & Aroma & Tekstur & Porositas Rasa & $\begin{array}{c}\text { Kesukaan } \\
\text { Keseluruhan }\end{array}$ \\
\hline $120: 90,150^{\circ} \mathrm{C}$ (G1S1) & 3.33 & 3.57 & 3.10 & 3.23 & 3.30 & 3.47 & 3.57 \\
$140: 70,150^{\circ} \mathrm{C}$ (G2S1) & 2.70 & 3.73 & 3.60 & 4.00 & 3.73 & 3.77 & 3.87 \\
$160: 50,150^{\circ} \mathrm{C}$ (G3S1) & 3.63 & 3.83 & 3.07 & 3.17 & 3.53 & 3.20 & 3.47 \\
$120: 90,170^{\circ} \mathrm{C}$ (G1S2) & 3.80 & 3.73 & 3.43 & 3.27 & 3.50 & 3.70 & 3.53 \\
$140: 70,170^{\circ} \mathrm{C}$ (G2S2) & 3.60 & 3.57 & 3.37 & 2.57 & 3.20 & 3.20 & 3.17 \\
$160: 50,170^{\circ} \mathrm{C}$ (G3S2) & 3.33 & 3.83 & 3.57 & 4.03 & 3.90 & 3.23 & 3.63 \\
\hline
\end{tabular}

Keterangan :Data merupakan rerata dari 30 panelis

\section{b. Metode skoring}

Metode skoring dilakukan dengan menggunakan pendekatan skala atau skor yang dihubungkan dengan deskripsi tertentu dari atribut mutu produk.

Tabel 5. Data Hasil Uji Skoring

\begin{tabular}{cccccccc}
\hline $\begin{array}{c}\text { Proporsi Telur : } \\
\text { Gula, Suhu } \\
\text { Pengovenan }\end{array}$ & $\begin{array}{c}\text { Warna } \\
\text { Crust }\end{array}$ & $\begin{array}{c}\text { Warna } \\
\text { Crumb }\end{array}$ & Aroma & Tekstur & Porositas & Rasa & $\begin{array}{c}\text { Penilaian } \\
\text { Keseluruhan }\end{array}$ \\
\hline $120: 90,150^{\circ} \mathrm{C}$ (G1S1) & 4.40 & 2.73 & 2.63 & 3.10 & 3.37 & 3.70 & 3.60 \\
$140: 70,150^{\circ} \mathrm{C}$ (G2S1) & 1.53 & 3.73 & 3.20 & 4.10 & 3.90 & 3.80 & 3.90 \\
$160: 50,150^{\circ} \mathrm{C}$ (G3S1) & 4.07 & 3.07 & 2.77 & 3.10 & 3.47 & 3.03 & 3.50 \\
$120: 90,170^{\circ} \mathrm{C}$ (G1S2) & 2.73 & 2.83 & 2.73 & 2.93 & 3.50 & 3.70 & 3.47 \\
$140: 70,170^{\circ} \mathrm{C}$ (G2S2) & 3.47 & 2.97 & 2.87 & 2.57 & 3.13 & 3.13 & 3.17 \\
$160: 50,170^{\circ} \mathrm{C}$ (G3S2) & 3.83 & 2.77 & 3.00 & 4.10 & 2.77 & 2.77 & 3.53 \\
\hline
\end{tabular}

Keterangan :Data merupakan rerata dari 30 panelis

Tabel 5 menunjukkan bahwa perlakuan $140 \mathrm{~g}: 70 \mathrm{~g}$ dengan suhu pengovenan $150^{\circ} \mathrm{C}$ memiliki penilaian keseluruhan tertinggi (3.90) karena diduga memiliki karaketristik yang mirip dengan bolu yang ada di pasaran. Proporsi ini mampu menghasilkan warna crumb kuning cerah dengan aroma yang sedap, tekstur yang empuk, dan porositas yang seragam. Pembentukan warna crust dipengaruhi oleh reaksi karamelisasi dan Maillard. Semakin tinggi penambahan telur dengan gula serta penggunaan suhu pengovenan yang tinggi akan menyebabkan pembentukan warna coklat yang semakin gelap (Purlis, 2010).

\section{Perlakuan Terbaik}

Penentuan perlakuan terbaik ini didapatkan berdasarkan hasil uji fisik dan organoleptik. Kemudian didapatkan perlakuan terbaik yaitu dengan proporsi telur dan gula $160 \mathrm{~g}: 50 \mathrm{~g}$ dengan suhu pengovenan $170^{\circ} \mathrm{C}$. Hasil perlakuan terbaik selanjutnya diuji karakteristik kimianya dan dibandingkan dengan bolu tepung terigu.

Tabel 6. Karakteristik Kimia Perlakuan Terbaik Bolu Bebas Gluten per $100 \mathrm{~g}$

\begin{tabular}{lcc}
\hline \multicolumn{1}{c}{ Parameter } & $\begin{array}{c}\text { Hasil Perlakuan } \\
\text { Terbaik } \\
\text { Kadar }(\%)\end{array}$ & $\begin{array}{c}\text { Bolu Tepung Terigu } \\
\text { Kontrol } \\
\text { Kadar }(\%)\end{array}$ \\
\hline Air $(\% \mathrm{~b} / \mathrm{b})$ & $47.26 \pm 4.48$ & $34.94 \pm 2.98$ \\
Karbohidrat $(\% \mathrm{~b} / \mathrm{b})$ & $35.80 \pm 4.78$ & $45.53 \pm 3.68$ \\
Lemak $(\% \mathrm{~b} / \mathrm{b})$ & $3.89 \pm 0.06$ & $4.55 \pm 0.13$ \\
Protein $(\% \mathrm{~b} / \mathrm{b})$ & $11.15 \pm 0.64$ & $14.16 \pm 0.70$ \\
Abu $(\% \mathrm{~b} / \mathrm{b})$ & $1.90 \pm 0.28$ & $0.82 \pm 0.14$ \\
\hline
\end{tabular}


Tabel 6 menunjukkan bahwa bolu bebas gluten memiliki kadar air yang lebih tinggi dibandingkan bolu tepung terigu. Hal ini disebabkan karena proses perebusan ubi kayu saat pembuatan pasta ubi kayu. Kandungan protein dan lemak yang cukup tinggi pada bolu bebas gluten dipengaruhi oleh penambahan telur. Kandungan protein pada telur berfungsi untuk menghasilkan busa yang mampu memperangkap udara dan gas kasbondioksida sehingga menyebabkan pengembangan volume (Belitz et al., 2009). Kandungan lemak (lesitin) berfungsi untuk menstabilkan aerasi adonan sehingga mampu memerangkap gas karbondioksida yang terbentuk dimana berpengaruh pada pembentukan volume bolu. Selain itu, kandungan lemak juga mempengaruhi keempukan (tenderness) bolu yang dihasilkan. Kadar abu yang tinggi pada bolu bebas gluten disebabkan karena kandungan abu ubi kayu yang lebih tinggi dibandingkan dengan tepung terigu yaitu $1 \%$ (SNI, 2006). Kadar karbohidrat dihitung melalui metode by difference sehingga hasilnya dipengaruhi kadar senyawa lainnya.

\section{SIMPULAN}

Perbedaan proporsi telur dan gula serta suhu pengovenan memberikan pengaruh nyata $(\alpha=0.05)$ terhadap karakterisktik organoleptik, volume pengembangan, porositas, warna crust, springiness, dan hardness, namun tidak memberikan pengaruh nyata terhadap parameter warna crumb dan cohesiveness. Perlakuan terbaik bolu bebas gluten yang dihasilkan adalah pada proporsi telur dan gula $160 \mathrm{~g}: 50 \mathrm{~g}$, dengan suhu pengovenan $170^{\circ} \mathrm{C}$ serta memiliki kadar air $47.26 \%$ karbohidrat $35.8 \%$, lemak $3.89 \%$, protein $11.15 \%$, dan abu $1.9 \%$.

\section{DAFTAR PUSTAKA}

AOAC. 1995. Official Methods of Analysis of The Association of Analytical Chemists. Association of Official Analytical Chemist Washington.

AOAC. 1999. Official Methods of Analysis of The Association of Analytical Chemist. Association of Official Analytical Chemist. Washington.

Bayon, M.A., Pozo, Rodriguez, A.R., Pernin, K. and Cayot, N. 2017. Aroma influence of Eggs on the Aroma Composition of A Sponge Cake and on the Aroma Release in Model Studies on Flavored Sponge Cakes. Journal of. Agricultural and Food Chemistry 55: 1418-1426.

Belitz, H.D., Grosch, W., and Schieberle, P. 2009. Food Chemistry. Springer Science and Business Media. USA.

Bennion, E.B., and Bamford, G.S.T. 1997. The Technology of Cake Making. Springer Science and Business Media. London.

El-Faham, S.Y., El-Rahiem, A., and Saleh, O.S. 2014. Free Gluten Cake and Tortilla from Cassava and Pre Gelatinized White Rice Flours. International Journal of Science and Research 3:10, 634-638.

Ghanbari, S., and Nader, H. 2015. Study of Texture and Color of The Sponge Cake Produced Using The Different Levels of Soy Flour. Indian Journal of Fundamental and Applied Life Sciences 5: S4, 1084-1089.

Goranova, Z., Baeva, M., Stankov, S., and Zsivanovits, G. 2015. Sensory Characteristic and Textural Changes during Storage of Sponge Cake with Functional Ingredient. Journal of Food Physics. 28-29: 70-79.

Hartajanie L., dan Ranie A. 2010. Peningkatan Kualitas Roti Non Terigu Berbasis Tepung Ubi Kayu (Manihot utilissima) Menggunakan Hidrokoloid dan Enzim. Skripsi. Universitas Katolik Soegijapranata. Semarang.

Jonathan, A.A.T., Trisnawati, C.Y., and Sutedja, A.M. 2016. Pengurangan Kuning Telur pada Beberapa Konsentrasi Gum Xanthan terhadap Karakteristik Fisikokimia dan Organoleptik Cake Beras Rendah Lemak. Jurnal Agroteknologi 10:1, 1-11.

Kartika, B.P.H., dan Supartono, W. 1988. Pedoman Uji Inderawi Bahan Pangan. Pusat Antar Universitas Pangan dan Gizi. Universitas Gadjah Mada. Yogyakarta. 
Kemendag. 2016. Perkembangan Ekspor Non Migas (Sektor) Periode: 2011-2016. http://www.kemendag.go.id/id/economic-profile/indonesia-export-import/growth-ofnon-oil-and-gas-export-sectoral. Tanggal akses: 26/9/2016.

Koswara, S. 2009. Tekonologi Pengolahan Telur. Ebookpangan.com. http://tekpan.unimus.ac.id/wp-content/uploads/2013/07/TEKNOLOGIPENGOLAHAN-TELUR.pdf. Tanggal akses: 9/1/2017.

Kusinska, E. 2007. Effect of Sugar Addition on Textural Properties of the Half-Short Cake. Journal of Food and Nutrition Science 57: 2A, 107-110.

Lin R.Y. 2014. Gluten Free Bread: Characterization and Development of Pre and Post Baked Gluten Free Bread. Thesis. Massachusetts Institut of Technology. Cambridge.

Lukman, I., Huda, N., dan Ismail, N. 2009. Physicochemical and sensory Properties of Commercial Chicken Nuggets. Asian Journal of Food Agroindustry 2: 2, 171-180.

Mohamad, R.A., Taip, F.S., Kamil, S.M.M., and Bejo, S.K. 2015. Color and Volume Development of Cake Baking and Its Influence on Cake Qualities. Journal of Applied Science and Agriculture. 10:5, 63-68.

Mudjisihono, R., Munarso, S.J., dan Noor, Z. 2000. Pengaruh Penambahan Tepung Kacang Hijau dan Gliseril Monostrearat pada Tepung Jagung terhadap Sifat Fisik dan Organoleptis Roti Tawar yang Dihasilkan. Jurnal Agritech. 13: 4, 1-6.

Phillips S. 2000. Eggs-Beating Technique for Egg Whites. https://www.craftybaking.com/howto/eggs-beating-techniques-egg-whites. Tanggal akses: 17/6/2017.

Purlis, E. 2010. Browning Development in Bakery Products-A Review. Journal of Food Engineering 99:3, 239-249.

Sanful, R.E., and Sophia, D. 2014. Production of Cocoyam, Cassava and Wheat Fluor Composite Rock Cake. Journal of Nutrition. 9: 8, 810-814.

Sani, N.A., Taip, F.S., Kamal, S.M.M., and Aziz, N.A. 2014. Effect of Temperature and Airflow on Volume Development during Baking and Its Influence on Quality of Cake. Journal of Engineering Science Technology 9:3, 303-313.

Sinha, N. 2007. Handbook of Food Products Manufacturing. Volume 2. John Wiley and Sons. New Jersey.

SNI. 2006. Tepung Terigu sebagai Bahan Makanan. BSN. SNI 01-3751-2006.

Sozer, N., Dogan, H., and Kokini, J.L. 2011. Textural Properties and Their Correlation to Cell Structure in Porous Food Materials. Journal of Agricultural and Food Chemistry. 59: 1498-1507.

Sudarmadji, S., Haryono, B., dan Suhardi. 1997. Prosedur Analisis untuk Bahan Makanan dan Pertanian. Liberty. Yogyakarta

Sunarto. 2002. Membuat Kerupuk Singkong dan Keripik Kedelai. Kanisius. Yogyakarta.

Ureta, M.M., Oliviera, D.F., and Salvadori, V.O. 2014. Quality Attribute of Muffin: Effect of Baking Operative Condition. Journal of Food Bioprocess Technology 7: 463-470.

Yuwono, S., dan Susanto, T. 1998. Pengujian Fisik Pangan. Universiats Brawijaya. Malang.

Zeleny, M. 1982. Multiple Criteria Decision Marking. Mc Graw Hill. New York. 